\title{
PRODUKTIVITAS PADI SAWAH PADA KEPADATAN POPULASI BERBEDA
}

\author{
Sumardi \\ Jurusan Budidaya Pertanian \\ Fakultas Pertanian Universitas Bengkulu \\ Jl. W.R. Supratman, Kandang Limun, Bengkulu. 38371 A \\ Sumardi_nora@yahoo.co.id
}

\begin{abstract}
[THE PRODUCTIVITY OF LOWLAND RICE UNDER DIFFERENT POPULATION DENSITIES]. Population density will determine the crop productivity on either individual plant basis or area basis. Objective of this study was to evaluate the productivity of lowland rice at different population densities. Rice variety IR-64 was planted on 13.2 $\mathrm{m} \times 10 \mathrm{~m}$ plot at four population densities $\left(16,25,49\right.$ and 100 plant $^{-2}$ ) in a completely randomized design with three replications. Observations were made on the yield components on individual plant basis and grain yield per area. Results indicated that tiller number, number of productive tiller, number of spikelet per panicle, number of fertile spikelet, and grain yield per hill were reduced as the population density was increased. On contrary, grain yield per $100 \mathrm{~m}^{2}$ was increased linearly in accordance to the increment of population density, where $47.57 \mathrm{~kg}$ grain per $100 \mathrm{~m}^{2}$ produced at the density of 16 plant $\mathrm{m}^{-2}$ and $86.53 \mathrm{~kg}$ was produced at the density of 100 plant $\mathrm{m}^{-2}$.
\end{abstract}

Keyword: lowland rice, productivity, population densities

\begin{abstract}
ABSTRAK
Kepadatan populasi memiliki peran penting dalam menentukan produktivitas tanaman baik secara individu maupun per satuan luas. Tujuan penelitian ini adalah untuk mengevaluasi produktivitas padi sawah pada kepadatan populasi yang berbeda. Padi varietas IR-64 yang ditanam pada plot yang berukuran $13.2 \mathrm{~m}$ x $10 \mathrm{~m}$ dengan empat kepadatan populasi $\left(16,25,49\right.$, dan 100 tanaman $\left.\mathrm{m}^{-2}\right)$ berdasarkan rancangan acak kelompok lengkap dengan 3 kali ulangan. Pengamatan dilakukan terhadap komponen hasil tanaman secara individu maupun hasil gabah per petak. Hasil penelitian menunjukkan bahwa jumlah anakan total dan jumlah anakan produktif, jumlah sipekelet per malai, jumlah spikelet fertile, dan hasil gabah per rumpun cenderung menurun seiring dengan peningkatan kepadatan populasi tanaman. Sebaliknya, hasil gabah per $100 \mathrm{~m}^{2}$ meningkat secara linier seiring dengan peningkatan kepadatan populasi tanaman, yakni $47.57 \mathrm{~kg}$ gabah per $100 \mathrm{~m}^{2}$ pada kepadatan populasi 16 tanaman $\mathrm{m}^{-2}$ dan $86.53 \mathrm{~kg}$ pada kepadatan populasi tanaman 100 tanaman $\mathrm{m}^{-2}$.
\end{abstract}

Kata kunci: padi sawah, produktivitas, kepadatan populasi 


\section{PENDAHULUAN}

Program ketahanan pangan diarahkan pada kemandirian petani yang berbasis pada potensi sumberdaya lokal melalui program peningkatan produksi pangan, menjaga ketersediaan pangan, aman dan dapat diakses oleh seluruh masyarakat di setiap daerah, serta antisipasi terhadap kemungkinan terjadinya kerawanan pangan. Oleh karena beras masih merupakan bahan pangan utama bagi sebagian besar masyarakat Indonesia, maka program tersebut masih difokuskan pada peningkatan produksi padi. Hal ini tersurat pada rumusan pembangunan pertanian bahwa sasaran peningkatan produksi komoditas utama tanaman pangan sampai tahun 2006 dan cadangan pangan pemerintah juga masih berbasis pada beras (Darwanto, 2005).

Melihat kenyataan ini, upaya peningkatan produktivitas tanaman padi menjadi fokus perhatian ke depan, sebab peningkatan produksi padi melalui program ekstensifikasi akan terkendala dengan ketersediaan lahan yang sesuai untuk budidaya padi sawah. Dipihak lain, lahan-lahan yang selama ini menjadi penyumbang utama produksi beras nasional telah mengalami pelandaian (leveling off) produktivitasnya. Terbukti bahwa selama lima tahun terakhir, produktivitas padi nasional tidak mengalami perubahan yang nyata. Rata-rata produktivitas lahan secara nasional tahun 2001 (4.39 ton ha $\left.{ }^{-1}\right), 2002$ (4.47 ton ha $\left.{ }^{-1}\right), 2003$ (4.54 ton $\left.\mathrm{ha}^{-1}\right), 2004\left(4.54 \mathrm{t} \mathrm{ha}^{-1}\right), 2005$ (4.57 ton ha $\left.{ }^{-1}\right)$ dan $2006\left(4,59\right.$ ton ha $\left.{ }^{-1}\right)$ (Sawit, 2006).

Berbagai upaya peningkatan produktivitas padi sawah telah dilakukan, antara lain melalui program integrated crop management (pengelolaan tanaman terpadu). Integrated crop management (ICM) seperti yang telah dikembangkan oleh Balitpa Sukamandi menekankan pada tiga komponen utama, yakni pengelolaan air secara intermitten, pengelolaan nutrisi, dan pemindahan bibit pada umur muda. Dalam pengujian, metode ini mampu menghasilkan gabah rata-rata 6.9 ton $\mathrm{ha}^{-1}$, sedangkan pada tingkat petani sebesar 5.4 ton ha ${ }^{-1}$ (Wardana et al., 2002). Metode ICM sesungguhnya sejalan dengan metode The System of Rice Intensification (SRI) yang dikembangkan di Madagaskar pada awal 1980-an. SRI juga merupakan metode peningkatan produktivitas tanaman padi sawah melalui intensifikasi lima komponen kultur teknis, yakni pengelolaan air yang tidak menggenang, umur pindah bibit muda, jarak tanaman longgar, tanaman satu bibit per titik, dan penambahan bahan organik (Uphoff, 2003). Kedua metode tersebut pada prinsipnya berupaya mengintegrasikan komponen-komponen kultur teknis sehingga bersinergi positif mendukung pertumbuhan dan perkembangan tanaman padi secara optimal guna menghasilkan peningkatan produktivitas secara signifikan.

Hasil pengujian lapang yang dilakukan Sumardi (2007) menunjukkan bahwa jumlah anakan total maksimum yang dapat dicapai melalui metode SRI dengan melibatkan semua komponen sebanyak 29 batang. Namun, dari jumlah anakan total tersebut hanya sekitar $79 \%$ diantaranya merupakan anakan produktif. Pada kondisi seperti ini produktivitas yang dicapai sudah cukup tinggi, yakni 6.76 ton ha $^{-1}$ gabah kering giling (GKG). Capaian produktivitas ini lebih tinggi lagi jika persentase anakan produktif yang dihasilkan dapat ditingkatkan melalui penurunan jumlah anakan tidak produktif yang secara fisiologis merupakan sink.

Venkateswarlu and Visperas (1987) mengemukakan bahwa upaya yang dapat dilakukan untuk meningkatkan produktivitas padi yang memiliki keterbatasan perimbangan antara source dan sink adalah melalui penurunan sink dengan meningkatkan jumlah malai per satuan luas. Hal ini dapat ditempuh dengan membatasi ruang tumbuh melalui peningkatan populasi tanaman per satuan luas agar anakan yang tumbuh terlambat dan tidak produktif dapat dikurangi. Zeng and Shannon (2000) melaporkan bahwa peningkatan populasi tanaman per satuan luas berkorelasi negatif dengan jumlah anakan yang dihasilkan, baik anakan total maupun anakan produktif, tetapi berkorelasi posistif dengan jumlah malai per satuan luas. Tujuan penelitian ialah untuk mengevaluasi produktivitas padi sawah pada kepadatan populasi yang berbeda sebagai upaya meningkatkan produktivitas padi sawah melalui peningkatan populasi tanaman.

\section{METODE PENELITIAN}

Penelitian ini dilaksanakan bulan Januari - Mei 2008 di Balai Benih Pembantu (BBP) Dinas Pertanian Kota Bengkulu di Kelurahan Semarang, Kota Bengkulu. Varietas padi yang digunakan adalah IR -64 dan ditanam pada 4 kepadatan populasi, yakni 16, 25, 49, dan 100 tanaman $\mathrm{m}^{-2}$ berdasarkan rancangan acak lengkap dengan 3 ulangan. Luas petak untuk setiap satuan percobaan adalah $13.2 \mathrm{~m}$ x $10 \mathrm{~m}$. Pengamatan dilakukan terhadap jumlah anakan total, jumlah anakan produktif, jumlah spikelet per malai, persentase spikelet fertil, dan bobot kering gabah per rumpun serta bobot kering gabah per petak efektif $\left(100 \mathrm{~m}^{2}\right)$. 
Kultur teknis yang digunakan mengacu pada metode SRI (the System of Rice Intensification). Pengolahan lahan dilakukan secara sempurna dengan satu kali pembajakan dan satu kali penggaruan. Pupuk kandang dengan dosis 5 ton ha ${ }^{-1}$ diberikan pada tanah yang telah dibajak dalam kondisi aerob (tidak tergenang). Penggenangan selama 3 hari dilakukan 7 hari setelah pembajakan dengan tujuan untuk melumpurkan tanah dan selanjutnya diikuti dengan penggaruan dan perataan tanah.

Persemaian dilakukan pada petak persemaian yang dibuat dengan kepadatan $1 \mathrm{~kg}$ benih untuk luas lahan semaian $40 \mathrm{~m}^{2}$. Penanaman dilakukan saat bibit berumur 12 hari setelah sebar benih dengan jumlah 1 bibit untuk tiap lubang tanam. Tanaman disusun berdasarkan pola bujur sangkar dengan legowo berukuran $40 \mathrm{~cm}$ pada tiap satu meter barisan tanaman. Pengairan dilakukan secara berselang (intermitten), yakni pemasukan air dihentikan ketika seluruh permukaan lahan digenangi hingga merata dengan kedalaman $2-3 \mathrm{~cm}$ dan selanjutnya lahan dibiarkan mengering secara alami. Pengairan berikutnya dilakukan jika pada permukaan tanah telah terdapat retakan-retakan kecil.

Penyiangan dilakukan secara manual dengan cara mencabut gulma yang tumbuh di antara tanaman pada umur 21 hari dan 40 hari setelah tanam. Pengendalian hama dan penyakit dilakukan dengan menggunakan pestisida dengan dosis sesuai dengan rekomendasi yang tertera pada kemasan.

\section{HASIL DAN PEMBAHASAN}

Jumlah anakan yang dihasilkan oleh tanaman padi sawah lebih ditentukan oleh periode pilokron yang dimiliknya hingga tanaman menghasilkan malai. Satu periode pilokron membutuhkan 5-7 hari bergantung pada kondisi lingkungan. Pada kondisi optimum fase vegetatif tanaman padi dapat berlangsung selama 12 pilokron sebelum tanaman menghasilkan malai. Dengan demikian, saat yang paling baik untuk transplanting bibit adalah selama pilokron ke-2 atau maksimum ke-3, sehingga pertumbuhannya tidak ketinggalan fase berlipat (eksponensial) yang dimulai pada pilokron ke-4 atau saat bibit berumur 8-15 hari setelah sebar benih (Berkelaar, 2001). Menurut Uphoff et al. (2002) bahwa jumlah anakan akan maksimal jika kesuburan tanah maupun ruang tumbuhnya optimal.

Oleh karena padi besifat merumpun melalui pembentukan anakan, maka penanaman dengan jarak tanam rapat mengakibatkan ruang tumbuh yang terbatas dan mengurangi produksi anakan, baik anakan total maupun anakan produktif. Anakan yang terbentuk pada kepadatan populasi tinggi adalah anakan primer dan sekunder, sedangkan anakan tersier yang terbentuk umumnya tidak mampu berkompetisi pada ruang tumbuh yang sempit. Dengan demikian, jumlah anakan tanaman padi pada jarak tanam rapat dapat akan lebih sedikit dibanding dengan tanaman yang ditanam pada jarak longgar. Gambar 1 menunjukkan bahwa jumlah anakan total per rumpun semakin rendah seiring dengan semakin sempitnya ruang tumbuh. Tanaman dengan kepadatan populasi 16 rumpun per meter persegi menghasilkan 35.78 anakan, sementara pada tanaman yang ditanam pada kepadatan 100 rumpun per meter persegi hanya menghasilkan 11.89 anakan. Pola yang sama terjadi pada anakan produktif. Tanaman padi yang ditanam pada kepadatan 16 rumpun per meter persegi menghasilkan 23.33 anakan produktif, namun jumlah ini menurun seiring dengan peningkatan populasi menjadi 100 rumpun per meter persegi, hanya menghasilkan 6.44 anakan produktif (Gambar 2).

Kepadatan populasi yang tinggi membatasi ruang tumbuh tanaman untuk menghasilkan pertumbuhan dan perkembangan organ tanaman secara optimal.

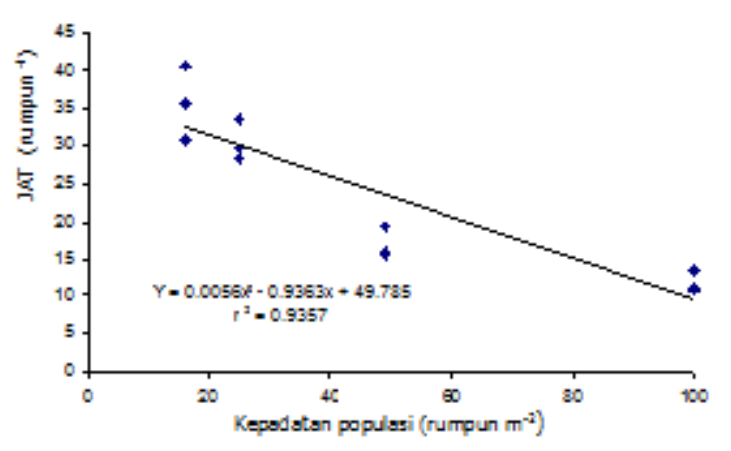

Gambar 1. Hubungan antara kepadatan populasi tanaman dan jumlah anakan total (JAT) tiap rumpun.

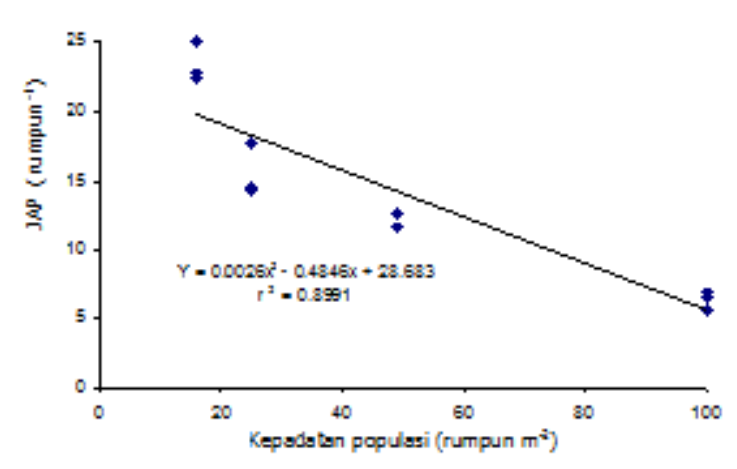

Gambar 2. Hubungan antara kepadatan populasi tanaman dan jumlah anakan produktif (JAP) tiap rumpun. 
Pada kepadatan populasi tinggi, malai yang dihasilkan akan berukuran lebih pendek dibanding kepadatan populasi rendah. Indikasi bahwa ukuran malai dipengaruhi oleh kepadatan populasi terlihat Gambar 3 yang menunjukkan bahwa jumlah spikelet tiap malai mengalami penurunan seiring dengan peningkatan kepadatan populasi tanaman. Jumlah spikelet tiap malai pada populasi 16 rumpun $\mathrm{m}^{-2}$ sebanyak 121.89 spikelet turun menjadi 94.33 spikelet dan ketika populasi dinaikkan menjadi 100 rumpun $\mathrm{m}^{-2}$. Hasil ini sejalan dengan Zeng and Shannon (2000) yang mengemukakan bahwa jumlah bulir gabah per tanaman, jumlah spikelet per malai, biji bernas per malai, bobot bagian atas tanaman dan indeks panen menurun seiring dengan peningkatan kepadatan populasi tanaman.

Persentase spikelet fertil ditentukan oleh dua faktor utama. Faktor pertama adalah kekuatan spikelet (sink) menarik hasil fotosintesis yang dilakukan oleh daun (source) dan mengakumulasikannya dalam bentuk pati yang disimpan di dalam spikelet yang disebut dengan bulir bernas. Faktor kedua adalah kemampuan source menghasilkan bahan kering untuk ditimbun ke bagian biji (sink) tanaman. Kedua faktor tersebut dipengaruhi oleh faktor lingkungan seperti air, unsur hara, cahaya, dan suhu (Sumardi, 2007).

Jumlah malai meningkat seiring dengan peningkatan jumlah populasi. Namun demikian peningkatan jumlah malai akan menurunkan bobot biji tiap rumpun dan persentase spikelet fertil (Counce, 1987; Wu et al., 1988; Counce and Wells, 1990; Miller et al., 1991; Gravois and Helms, 1992;). Hal ini terjadi karena adanya kompetisi antara tanaman dalam memanfaatkan faktor lingkungan seperti air, cahaya dan unsur hara (Evans and De Datta, 1979), serta ruang tumbuh (Jones and Snyder, 1987; Counce

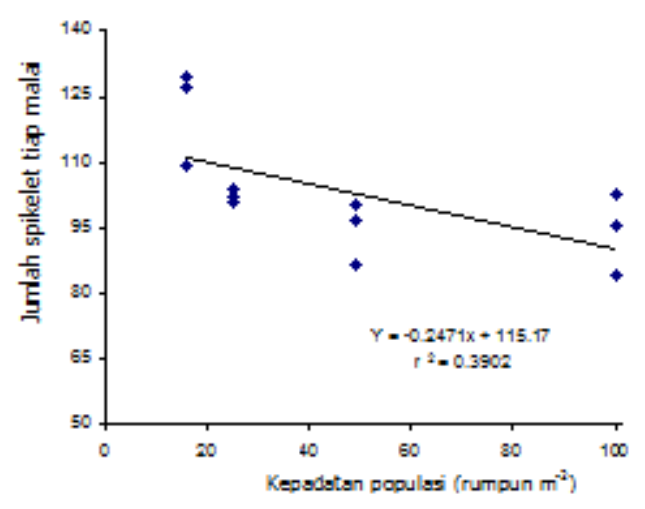

Gambar 3. Hubungan antara kepadatan populasi tanaman dan jumlah spikelet tiap malai. and Wells. 1990). Hasil penelitian menunjukkan bahwa persentase spikelet fertil menurun seiring dengan peningkatan kepadatan populasi. Persentase spikelet fertil sebesar $93.05 \%$ pada populasi 16 rumpun $\mathrm{m}^{-2}$, turun menjadi $90.41 \%$ pada populasi 100 rumpun $\mathrm{m}^{-2}$ (Gambar 4). Kondisi serupa juga terjadi pada bobot kering gabah per rumpun. Pada populasi 16 rumpun $\mathrm{m}^{-2}$ diperoleh gabah kering per rumpun sebesar $39.64 \mathrm{~g}$ dan turun menjadi 11.40 g pada populasi 100 rumpun per $\mathrm{m}^{2}$ (Gambar 5).

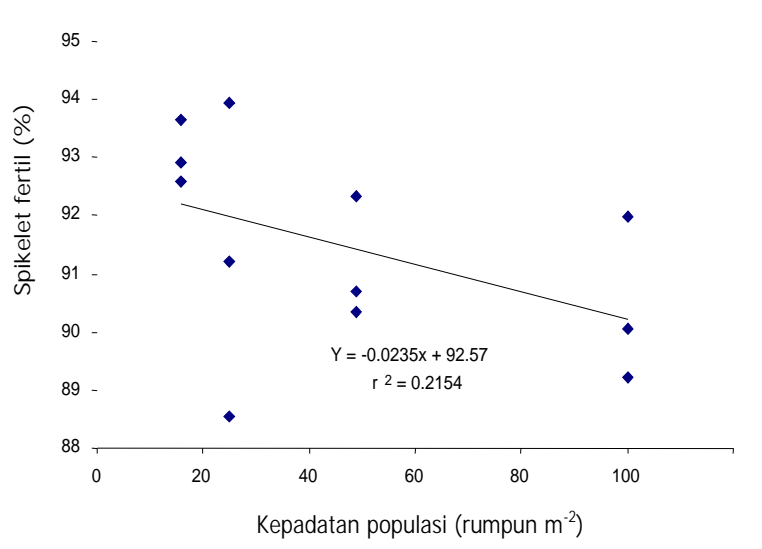

Gambar 4. Hubungan antara persentase spikelet fertil dan kepadatan populasi tanaman padi.

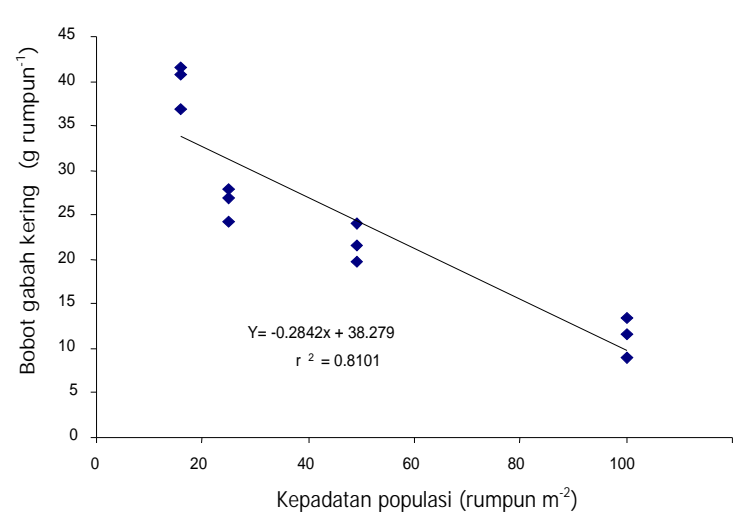

Gambar 5. Hubungan bobot gabah kering tiap rumpun dan kepadatan populasi tanaman padi.

Populasi 16 rumpun $\mathrm{m}^{-2}$ menghasilkan 368 malai, sebaliknya populasi 100 rumpun $\mathrm{m}^{-2}$ dapat menghasilkan 644 malai. Berdasarkan perbandingan ini, meskipun jumlah bulir per malai pada populasi yang padat lebih sedikit sehingga bobot gabah tiap rumpunnya akan rendah, namun bobot gabah per satuan luas akan lebih tinggi. Hasil percobaan menunjukkan bahwa bobot gabah pada 16 rumpun $\mathrm{m}^{-2}$ adalah $39.64 \mathrm{~g}$, sedangkan pada 100 rumpun $\mathrm{m}^{-2}$ adalah $11.40 \mathrm{~g}$. Keadaan sebaliknya terjadi pada pengamatan bobot gabah kering per petak, 
yakni kepadatan populasi rendah menghasilkan bobot gabah kering lebih tinggi rendah kepadatan populasi tinggi. Populasi dengan kepadatan 16 rumpun $\mathrm{m}^{-2}$ menghasilkan gabah kering giling per petak efektif sebesar $47.57 \mathrm{~kg}$, sementara tanaman yang ditanam pada kepadatan populasi 100 rumpun $\mathrm{m}^{-2}$ menghasilkan $85.53 \mathrm{~kg}$ gabah kering giling (Gambar 6). Hasil ini menunjukkan bahwa peningkatan kepadatan populasi hingga 100 rumpun $\mathrm{m}^{-2}$ dapat meningkatkan produktivitas lahan. Hal ini sejalan dengan pendapat Zeng dan Shannon (2000) bahwa hasil gabah meningkat seiring dengan peningkatan populasi per satuan luas lahan. Jarak tanam yang rapat pada tanaman akan memberikan beberapa keuntungan, antara lain: 1) energi awal yang dibutuhkan untuk pemanjangan akar relatif kecil, 2) akar yang dibutuhkan relatif tidak panjang, 3) lebih cepat mencapai sumber hara, terutama nitrogen, dan 4) lebih singkat hara menuju daun (Salisbury and Ross, 1985).

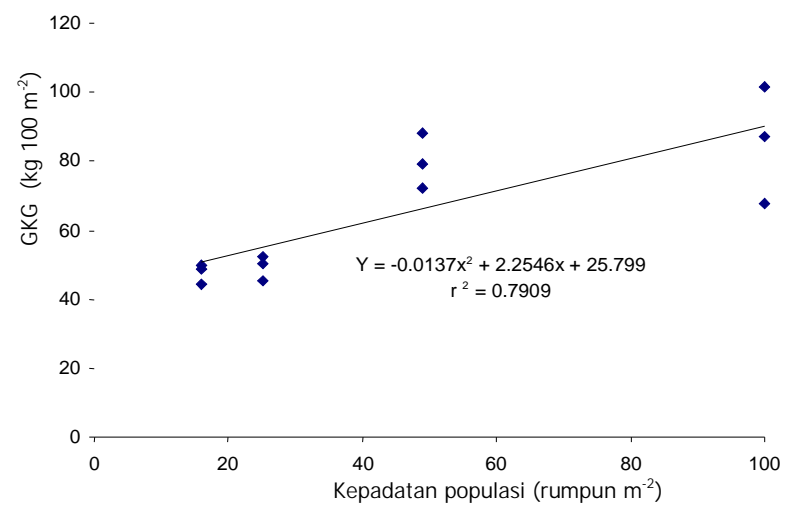

Gambar 6. Hubungan antara bobot gabah kering giling (GKG) dan kepadatan populasi tanaman .

Hasil penelitian ini membuka pemikiran baru dalam upaya peningkatan produktivitas padi pada lahan sawah melalui peningkatan kepadatan populasi. Namun demikian, untuk mengimplementasikan pemikiran tersebut, maka berbagai faktor yang berhubungan dengan proses produksi padi sawah perlu mendapat pertimbangan yang cermat. Menanam padi dengan populasi yang rapat membutuhkan tenaga kerja yang jauh lebih besar dibandingkan dengan populasi yang longgar. Disamping itu, proses pemeliharaan, khususnya penyiangan juga membutuhkan tenaga kerja yang lebih besar, sehingga inovasi teknologi budidaya padi sawah dengan populasi yang padat masih sangat diperlukan, antara lain teknik tanam benih langsung (tabela) dengan sistem hambur dan larikan perlu diteliti lebih lanjut.

\section{KESIMPULAN}

Peningkatan kepadatan populasi dari 16 rumpun $\mathrm{m}^{-2}$ menjadi 25, 49 dan 100 rumpun $\mathrm{m}^{-2}$ menurunkan jumlah anakan total, jumlah anakan produktif, jumlah spikelet per malai, persentase spikelet fertil, bobot gabah tiap rumpun, namun meningkatkan bobot gabah kering giling per petak $\left(100 \mathrm{~m}^{2}\right)$, yakni 47.57 $\mathrm{kg}$ per petak pada kepadatan populasi 16 rumpun $\mathrm{m}^{-2}$ dan $85.53 \mathrm{~kg}$ per petak pada kepadatan populasi 100 rumpun $\mathrm{m}^{-2}$.

\section{SANWACANA}

Terima kasih penulis ucapkan kepada Kepala Dinas Pertanian Kota Bengkulu, Kepala Balai Benih Pembantu (BBP) Dinas Pertanian Kota Bengkulu, Rahmat (Mahasiswa Jurusan Budidaya Pertanian Fakultas Pertanian Universitas Bengkulu, Suyono SP (Staf Laboratorium Agronomi, Fakultas Pertanian Universitas Bengkulu) yang telah membantu terlaksananya penelitian ini.

\section{DAFTAR PUSTAKA}

Berkelaar, D. 2001. Sistem intensifikasi padi (The System of Rice Intensification-SRI). Sedikit dapat memberi lebih banyak. Buletin ECHO Development Notes, Januari 2001. ECHO Inc. 17391 Durance Rd. North Ft. Myers F1.33917 USA. pp. 1-6.

Counce, P.A. 1987. Asymtotic and parabolic yield and linear nutrient content responses to rice population density. Agron. J. 79: 864-869.

Counce, P.A. and B.R.Wells. 1990. Rice plant population density effect on early-season nitrogen requirement. J. Prod. Agric. 3: 390-393.

Darwanto, D.H. 2005. Ketahanan pangan berbasis produksi dan kesejahteraan petani. Ilmu Pertanian 12: 152-164.

Evans, L.T. and S.K. De Datta. 1979. The relation between irradiance and grain yield of irrigated rice in the tropics, as influenced by cultivars, nitrogen fertilizer application and month of planting. Field Crops Res. 2: 1-17.

Gravois, K.A. and R.S. Helms. 1992. Path analysis of rice yield and yield components as affected by seeding rate. Agron. J. 84: 1-4.

Miller, B.C., J.E. Hill, and S.R. Roberts. 1991. Plant population effects on growth and yield in water-seeded rice. Agron. J. 83: 291-297.

Salisbury, F.B., and C.W. Ross. 1985. Plant Physiology. Wadsworth Publishing Co., Belmont, California.

Sawit, M.H. 2006. Indonesia dalam tatanan perubahan perdagangan beras dunia. Makalah BPS di Rakornas Inpres, Yogyakarta 1-2 Mei 2006. 


\section{SUMARDI}

Sumardi. 2007. Peningkatan produktivitas padi sawah melalui perbaikan lingkungan tumbuh dalam meningkatkan hubungan source-sink tanaman pada metode SRI (The System of Rice Intensification). Disertasi. Program Pascasarjana Universitas Andalas, Padang. Tidak dipublikasikan

Uphoff, N., S. Rafaralaby, and J. Rabenandrasana, 2002. What is System of Rice Intesification. Cornell International Institute for Food, Agriculture and Development. http://cifad.cornell.edu/sri.

Uphoff, N. 2003. Initial Report on China National S.R.I. Workshop. Hangzhon, March 2-3,2003.

Venkateswarlu, B. and R.M. Visperas. 1987. Source-Sink Relationships in Crop Plants. International Rice Research Institute. Manila, Philippines
Wardana, I.P., P.S. Bindraban, A. Gani, A.K. Makarim, and I. Las. 2002. Biophysical and Economic Implication of Integrated Crop and Resource Management for Rice in Indonesia. Proceedings of A Thematic Workshop on Water-Wise Rice Production, 8-11 April 2002 at IRRI Headquarters in Los Banos, Philippines.

Wu, G., L.T. Wilson, and A.M. McClung. 1988. Contribution of rice tiller to dry matter accumulation and yield. Agron. J. 90: 317-323.

Zeng, L. and M. C. Shannon. 2000. Effects of salinity on grain yield and yield components of rice at different seeding densities. Agron. J. 92: 418-423. 